\title{
ЕКСПЕРИМЕНТАЛЬНЕ ДОСЛІДЖЕННЯ МЕДІАТОРНИХ МЕХАНІЗМІВ АНТИНОЦИЦЕПТИВНОЇ ДІЇ 4-[4-ОКСО-(4Н)-ХІНАЗОЛІН-3-ІЛ] БЕНЗОЙНОї КИСЛОТИ (СПОЛУКИ ПК-66)
}

Вступ. У попередніх дослідженнях встановлено, що серед похідних 4-оксо (аміно-) хіназоліну речовиною-лідером із вираженою знеболювальною дією на різних моделях больової перцепції є 4-[4-оксо-(4H)-хіназолін-3-іл] бензойної кислоти (сполука ПК-66).

Мета дослідження - ґрунтовно вивчити основні механізми аналгетичної дії нового оригінального похідного хіназолінів - сполуки ПК-66.

Методи дослідження. Антиноцицептивну дію сполуки ПК-66 (1 мг/ка внутрішньочеревно) вивчали в щурів на моделі гіпералгезії, викликаної субплантарним введенням у ліву задню кінцівку тварини 0,1 мл 1 \% розчину карагеніну, 2 \% суспензії зимозану та 0,01% розчину брадикініну. Ступінь ноцицепції визначали за допомогою долориметра шляхом оцінювання порога больової чутливості. Як рефреренс-препарати використовували диклофенак натрію (4 мг/кг) та корвітин (5 мг/кг). Аналгетичну активність досліджуваних сполук оцінювали за їх здатністю збільшувати поріг больової чутливості в дослідних групах порівняно з групою контролю і виражали у відсотках. Антиексудативну активність сполуки та реореренс-препаратів визначали шляхом вимірювання об'єму набряку лапки за допомогою плетизмометра за ступенем зменшення набряку в піддослідних тварин порівняно зі щурами групи контролю і виражали у відсотках.

Результати й обговорення. Сполука ПК-66 здатна усувати гіпералгезію, яку викликали різні альгогени. Найбільш виражено ії знеболювальна дія проявлялась на тлі введення брадикініну (53,4 \%), менш виражену антиноцицепцію спостерігали при карагеніновому набряку (38,5%), найменш вираженою ця дія була на моделі зимозанової гіпералгезії (26,9%). Дослідження антиексудативної дії продемонструвало, що антифрлогогенна дія сполуки ПК-66 більшою мірою проявлялась на моделі карагенінового набряку (16,1%), ніж зимозанового (12,8 \%). Однак цей ефект не сягав статистично вірогідних значень ні при карагеніновому, ні при зимозановому набряку і в обох випадках значно поступався препаратам порівняння - диклооренаку натрію (58,3 \%) та корвітину (52,3\%).

Висновок. Антимедіаторна дія сполуки ПК-66 більшою мірою зумовлена антагонізмом до брадикініну, меншою - до простагландинів та лейкотрієнів.

КЛЮчОВІ СЛОВА: 4-[4-оксо-(4Н)-хіназолін-3-іл] бензойної кислоти; ноцицепція; медіаторні механізми; брадикінін.

ВСТУП. Біль - це один із найрозповсюдженіших симптомів у клінічній практиці та одна 3 головних причин звернення населення за медичною допомогою [1, 2]. Майже 90 \% захворювань супроводжуються больовим синдромом різного ступеня вираження [3, 4]. Він супроводжується органічними і фрункціональними змінами в організмі, призводить до психоемоційних розладів, у т. ч. й депресивних, впливає на працездатність, фрункціональну активність та якість життя людини [5-7]. Больовий синдром ускладнює перебіг будь-якого захворювання, погіршує стан хворого за рахунок активації "стрес-відповіді", довшим стає одужання.

(с Г. І. Крамар, Г. І. Степанюк, Н. І. Волощук, О. І. Альчук, 2019.
Незважаючи на значний прогрес у розумінні фрізіологічних, нейрофрізіологічних іпсихологічних механізмів болю, наявність великої кількості лікарських засобів, здатних усувати больовий синдром, проблема болю і боротьби з ним залишається до кінця не вирішеною. Тому важко переоцінити значення пошуку та розробки біологічно активних сполук із знеболювальною дією. Серед різних класів хімічних речовин досить перспективними виявились похідні 4-оксо (аміно-) хіназоліну. За даними літератури [8, 9], сполуки цього класу показали церебро- та актопротекторні й антиноцицептивні властивості [10], а також досить низьку токсичність [11]. Наші попередні дослідження довели наявність серед сполук цього класу речовини-лідера з вираже- 
ною знеболювальною дією на різних моделях больової перцепції - 4-[4-оксо-(4H)-хіназолін-3іл] бензойної кислоти (сполуки ПК-66) [10, 12], а також її більшу безпечність щодо шлунково-кишкового тракту порівняно з диклофенаком натрію та кеторолаком [13, 14].

Сполука ПК-66 належить до ненаркотичних аналгетиків, оскільки в неї відсутній опіоїдергічний компонент дії [15]. Також проведено поглиблене дослідження диореренціації центрального і периферичного компонентів антиноцицептивної дії ПК-66 на моделі фрормалінового тесту [14].

Встановлено, що в механізмах аналгетичної дії сполуки ПК-66 бере участь адренергічна система, зокрема $\alpha_{2}$-адренорецептори, дофамінергічна та ГАМК-ергічна системи [15].

Сприйняття, передача й аналіз ноцицептивної інфрормації та фрормування больового відчуття відбуваються з участю центральних і перифреричних нейрональних утворів та складаються 3 таких процесів, як [16, 17]: трансдукція, трансмісія, модуляція і перцепція больового відчуття. Сприйняття болю забезпечує складна ноцицептивна система, що включає в себе особливу групу перисреричних рецепторів і нейронів, які розташовані в багатьох структурах нервової системи та реагують на ушкоджувальну дію. Больові синдроми, які виникають внаслідок активації ноцицептивних рецепторів при травмі, запаленні, ішемії та ін., належать до соматогенних. При цьому відзначають сенситизацію ноцицепторів до дії ушкоджувальних стимулів. Причиною її є вивільнення в зоні ушкодження медіаторних молекул як плазмового походження (брадикінін, калідин), так і клітинних (гістамін, інтерлейкін 1, фрактор некрозу пухлини, лейкотрієни, серотонін, аденозинтрифросфрат, ендотеліни, простагландини, оксид азоту тощо [18-20].

Тому ми вивчали вплив досліджуваної сполуки ПК-66 на основні периферичні механізми формування болю, пов'язані 3 пригніченням синтезу біогенних амінів та кінінів, лейкотрієнів і простагландинів. Досліджували також і антиексудативні властивості сполуки, оскільки вони теж відіграють важливу роль у механізмі периореричної аналгетичної дії, адже медіатори болю $є$ одночасно і медіаторами запалення та виділяються в періоди загострення запального процеcy [21].

Механізмів периферичного компонента дії сполуки ПК-66 не вивчали, що і стало підставою для проведення цього дослідження.

Мета дослідження - ґрунтовно вивчити основні механізми реалізації аналгетичної дії нового оригінального похідного хіназолінів - сполуки ПК-66.
МЕТОДИ ДОСЛІДЖЕННЯ. Досліди виконано на 56-ти білих щурах-самцях лінії Вістар масою 220-250 г, отриманих з віварію ДУ "Інститут фрармакології та токсикології НАМН України". Протягом експерименту тварини перебували в стандартних умовах віварію Вінницького національного медичного університету імені М. І. Пирогова (ВНМУ) на харчовому раціоні, збалансованому за всіма нутрієнтами, 3 12-годинним освітленням (день/ніч) та вільним доступом до води. При проведенні дослідження було дотримано вимог Європейської конвенції про захист хребетних тварин, що використовуються для дослідних та інших наукових цілей (Страсбург, 1986), що підтверджено висновком комітету 3 біоетики ВНМУ.

Антиноцицептивну дію сполуки ПК-66 вивчали на моделі гіпералгезії, викликаної субплантарним введенням у ліву задню кінцівку тварини 0,1 мл 1 \% розчину карагеніну ("Sigma”, США), 2 \% суспензії зимозану ("Sigma”, США) та 0,01 \% розчину брадикініну ("Sigma”, США). Ступінь ноцицепції визначали за допомогою долориметра ("Dolorimeter Baseline", США) шляхом оцінювання порога больової чутливості (ПБЧ) - мінімаль-

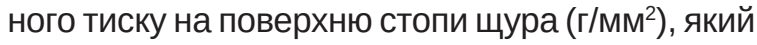
викликав больову реакцію у тварини. Порівнювали ПБч на кінцівці до початку дослідження (вихідне значення), а також через 1 хв, 0,5 та 3 год після введення брадикініну, зимозану і карагеніну відповідно [22]. Аналгетичну активність досліджуваних сполук оцінювали за їх здатністю збільшувати поріг больової чутливості в дослідних групах порівняно з групою контролю і виражали у відсотках; розрахунок проводили за фрормулою:

$$
A A=\frac{\left(\Delta \Pi Б Ч_{K}-\Delta \Pi Б Ч_{A}\right)}{\Delta \Pi Б Ч_{K}} \times 100 \%,
$$

де $\mathrm{AA}$ - аналгетична активність, \%;

$\triangle П Б Ч_{к}-$ середня різниця значень порога больової чутливості між здоровою та ушкодженою кінцівками у тварин групи контролю;

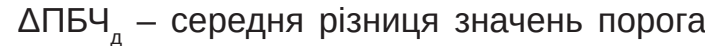
больової чутливості між здоровою та ушкодженою кінцівками у тварин дослідної групи.

Антиексудативну активність сполуки та рефреренс-препаратів визначали шляхом вимірювання об'єму набряку лапки за допомогою плетизмометра (“Ugo Basil”, Італія) за ступенем зменшення набряку в піддослідних тварин порівняно зі щурами групи контролю і виражали у відсотках; розрахунок проводили за фрормулою:

$$
\mathrm{AEA}=\frac{\Delta \mathrm{V}_{\mathrm{K}}-\Delta \mathrm{V}_{\mathrm{A}}}{\Delta \mathrm{V}_{\mathrm{K}}} \times 100 \%,
$$

де AEA - антиексудативна активність, \%;

$\Delta \mathrm{V}_{\mathrm{k}}$ - середня різниця в об'ємі між набряклою та ненабряклою лапками в групі контролю; 
$\Delta \mathrm{V}_{\text {д }}$ - середня різниця в об'ємі між набряклою та ненабряклою лапками в дослідній групі.

Досліджувану сполуку вводили в її середньоефективній дозі $\left(\right.$ ЕД $\left._{50}\right)$ за аналгетичною активністю, визначеною в попередніх дослідженнях, що становила 1 мг/кг внутрішньочеревно. Як референс-препарати використовували диклосренак натрію (4 мг/кг, "Диклоберл", BerlinChemie AG) та корвітин (5 мг/кг, Борщагівський ХФЗ). Вводили сполуку ПК-66, корвітин і диклофенак натрію за 2, 1,5 та 1 год до введення брадикініну, зимозану і карагеніну відповідно.

Тварини групи контролю отримували еквіоб'ємну кількість розчинників. Обробку отриманих результатів проводили методами варіаційної статистики в програмі STATISTICA 8.0 з використанням непараметричних методів аналізу [23].

РЕЗУЛЬТАТИ Й ОБГОВОРЕННЯ. ОТРИМаНі результати показали, що сполука ПК-66 здатна усувати гіпералгезію, яку викликали різні альгогени. Найбільш виражено її знеболювальна дія проявлялась на тлі введення брадикініну, при цьому АА сполуки становила 53,4 \% (табл. 1). Менш виражену антиноцицепцію спостерігали при карагеніновому набряку (АА сягала 38,5 \%).
Найменш вираженою ця дія була на моделі зимозанової гіпералгезії (АА становила лише $26,9 \%)$.

Водночас дослідження антиексудативної дії продемонструвало, що антисрлогогенна дія сполуки ПК-66 більшою мірою проявлялась на моделі карагенінового набряку (АЕА становила $16,1 \%$ ), ніж зимозанового (AЕA - 12,8 \%) (табл. 2). Однак цей есрект не сягав статистично вірогідних значень ні при карагеніновому, ні при зимозановому набряку і в обох випадках значно поступався препаратам порівняння - диклосренаку натрію (AEA - 58,3 \%) та корвітину (AEA $52,3 \%)$

Отримані дані дають змогу вважати, що в механізмах аналгетичної дії нового похідного хіназоліну найбільшою мірою бере участь антибрадикініновий компонент, найменшою - антилейкотрієновий (оскільки сполука ПК-66 має незначну спроможність усувати гіперальгезію та набряк, викликаний зимозаном, у механізмі дії якого беруть участь ці біологічно активні молекули). що стосується антипростагландинового компонента дії сполуки, то її аналгетична дія на тлі введення карагеніну переважала антифрлогогенну і поступалась класичному неселективному інгібітору ЦОГ-1 та ЦОГ-2 - диклофренаку

Таблиця 1 - Аналгетична дія сполуки ПК-66 за умов їі внутрішньочеревного введення в дозі ЕД

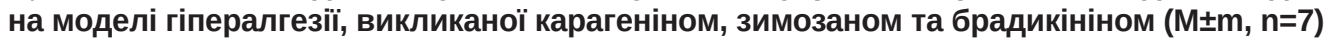

\begin{tabular}{|c|c|c|c|c|}
\hline Група тварин & $\begin{array}{c}\text { Вихідне значення } \\
\text { ПБЧ }\end{array}$ & $\begin{array}{c}\text { Після введення } \\
\text { альгогену }\end{array}$ & $\begin{array}{c}\text { \% відносно } \\
\text { вихідного значення }\end{array}$ & $\mathrm{AA}, \%$ \\
\hline \multicolumn{5}{|c|}{ Карагенін (0,1 мл 1 \%) } \\
\hline Контроль & $507,10 \pm 21,40$ & $292,10 \pm 9,75^{\star}$ & $-42,2$ & 0 \\
\hline ПК-66 & $522,10 \pm 22,10$ & $390,00 \pm 22,60$ & $-25,5$ & 38,5 \\
\hline \multicolumn{5}{|c|}{ Зимозан (0,1 мл 2 \%) } \\
\hline Контроль & $478,80 \pm 18,30$ & $320,00 \pm 15,40^{*}$ & $-34,4$ & 0 \\
\hline ПК-66 & $456,80 \pm 17,50$ & $334,30 \pm 16,60^{*}$ & $-26,8$ & 26,9 \\
\hline \multicolumn{5}{|c|}{ Брадикінін (0,1 мл 0,01 \%) } \\
\hline Контроль & $462,90 \pm 23,90$ & $147,10 \pm 8,65^{*}$ & $-67,9$ & 0 \\
\hline ПК-66 & $449,30 \pm 12,60$ & 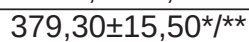 & $-15,7$ & 53,4 \\
\hline
\end{tabular}

Примітка. * - статистично вірогідні відмінності $(p<0,05)$ відносно вихідного значення; ** - статистично вірогідні відмінності $(p<0,05)$ відносно групи контролю.

Таблиця 2 - Антиексудативна дія сполуки ПК-66, диклофенаку натрію і корвітину за умов

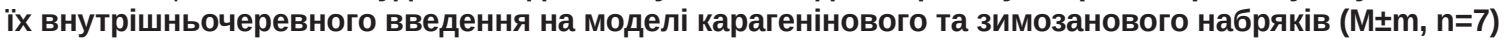

\begin{tabular}{|c|c|c|c|c|}
\hline Група тварин & $\begin{array}{c}\text { Об'єм ушкодженої } \\
\text { кінцівки, см }{ }^{3} \\
\end{array}$ & $\begin{array}{c}\text { Об'єм здорової } \\
\text { кінцівки, см }{ }^{3} \\
\end{array}$ & $\begin{array}{c}\text { Приріст об'єму, } \\
\text { см }^{3}\end{array}$ & AEA, \% \\
\hline \multicolumn{5}{|c|}{ Карагенін (0,1 мл 1 \%) } \\
\hline Контроль & $756,50 \pm 46,80$ & $369,60 \pm 39,00$ & $386,90 \pm 62,20$ & 0 \\
\hline ПК-66 & $709,90 \pm 95,30$ & $385,40 \pm 37,80^{\star}$ & $324,50 \pm 80,50$ & 16,1 \\
\hline Диклофенак натрію & $632,80 \pm 78,80$ & $471,50 \pm 96,10 * / \star \star$ & $161,30 \pm 31,90$ & 58,3 \\
\hline \multicolumn{5}{|c|}{ Зимозан (0,1 мл 2\%) } \\
\hline Контроль & $916,40 \pm 31,20$ & $435,30 \pm 75,10$ & $481,10 \pm 78,40$ & 0 \\
\hline ПК-66 & $869,10 \pm 41,50$ & $450,00 \pm 21,00^{*}$ & $419,20 \pm 56,40$ & 12,8 \\
\hline Корвітин & $669,00 \pm 93,70$ & 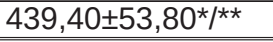 & $229,60 \pm 56,60$ & 52,3 \\
\hline
\end{tabular}

Примітка. * - статистично вірогідні відмінності $(p<0,05)$ між ушкодженою та неушкодженою кінцівками; *夫 - статистично вірогідні відмінності (p<0,05) відносно групи контролю. 
натрію. Ці результати зіставляються з відсутністю в даної сполуки статистично вірогідної дії на 2-гу фразу фрормалінового тесту [12] та ульцерогенної дії як в інтактних тварин, так і в щурів 3 експериментальним запальним процесом [13]. Водночас на моделі автоімунного запального процесу [24] сполука ПК-66 проявляла аналгетичну та незначну протизапальну активність. Це, на нашу думку, може бути пов'язано з відсутністю в досліджуваного похідного хіназоліну інгібуючого впливу на ЦОГ-1 і можливим впливом на ЦОГ-2, оскільки протизапальна та, більшою мірою, знеболювальна дія проявлялась на моделі запальних процесів [25, 26]. Можливим $є$ також існування інших механізмів реалізації аналгетичної активності досліджуваної сполуки, однак це потребує подальших досліджень.

ВИСНОВОК. У механізмі антиексудативного (протизапального) есректу сполуки ПК-66, як і в механізмі аналгетичного, домінуючу роль, імовірно, відіграє антибрадикінінова дія, меншою мірою - здатність інгібувати утворення лейкотрієнів та простагландинів. У цьому відношенні сполука ПК-66 поступається, відповідно, кверцетину (на моделі зимозанового набряку) та диклофенаку (на моделі карагенінового набряку).

\section{СПИСОК ЛІТЕРАТУРИ}

1. Быков Ю. Н. Диагностика и лечение нейропатической боли при заболеваниях периферической нервной системы / Ю. Н. Быков, Г. Ю. Левина, С. Б. Алексеев // Сибир. мед. журн. - 2015. - № 3. C. $28-30$.

2. Зозуля І. С. Біль: підходи до діагностики та лікування в неврології та хірургії/І. С. Зозуля, М. В. Максименко, А. І. Зозуля // Укр. мед. часоп. - 2016. № 2 (112). - С. 37-39.

3. Корж А. Н. Острый болевой синдром в практике семейного врача [Электронный ресурс] / А. Н. Корж. 2017. - Режим доступа: http://www.mif-ua.com/archive/ article/44421\#prettyPhoto.

4. Use of Complementary Health Approaches for Musculoskeletal Pain Disorders Among Adults: United States, 2012 / T. C. Clarke, R. L. Nahin, P. M. Barnes B. J. Stussman // Natl. Health Stat. Report. - 2016. 98. - P. 1-12.

5. Мамчур В. Й. Депресія та біль: деякі питання коморбідності та лікування (огляд) / В. Й. Мамчур, О. В. Хом'як // Морфологія. - 2011. - № 3. - С. 24-34.

6. Severe chronic pain is associated with increased 10 year mortality. A cohort record link-age study / N. Torrance, A. M. Elliot, A. J. Lee, B. H. Smith // European Journal of Pain. - 2010. - No. 14. - P. 380-386.

7. Morgan B. Diagnosis and treatment of common pain syndromes and disorders / B. Morgan, S. Wooden // Nurs. Clin. North. Am. - 2018. - 53, No. 3. - P. 349-360. DOI: 10.1016/j.cnur.2018.04.004.

8. Ходаківський О. А. Нейропротекторна дія похідних 4-оксо(аміно) хіназоліну при експериментальній ішемії головного мозку : автореф. дис. на здобуття наук. ступеня канд. мед. наук / О. А. Ходаківський. Одеса, 2009. - 21 с.

9. Альчук О. І. Актопротекторні властивості нових похідних 4-оксо(аміно-)хіназоліну (експериментальне дослідження) : автореф. дис. на здобуття наук. ступеня канд. мед. наук / О. І. Альчук. - К., 2011. - 20 с.

10. Юрченко А. І. Скринінг аналгетичної дії похідних 4-оксо(аміно-) хіназоліну / А. І. Юрченко // Фарма- кологія та лікар. токсикологія. - 2013. - № 2 (33). C. 89-91.

11. Павлов С. В. Церебропротективна активність похідних (4-оксо-4-Н-хіназолін-3-іл)-алкіл (арил) карбонових кислот в умовах іммобілізаційного стресу : авторефр. дис. на здобуття наук. ступеня канд. мед. наук / С. В. Павлов. - К., 2007. - 17 с.

12. Kramar H. I. Experimental study of analgesic effect of new 3-(2-R1-6-R2-4-oxyquinoline-3(4H)-yl)alkyl (alkaryl, aryl) carboxylic acid derivative (PC-66 compound) / H. I. Kramar // Curierul Medical. - 2017. No. 1. - P. 32-34.

13. Kramar H. I. Experimental study of state of gastric mucosa in rats under introduction of new derivate of 4-[4-oxo-4h-quinazoline-3-yl] benzoic acid (pc-66) / H. I. Kramar // ScienceRise: Pharmaceutical Science. 2017. - No. 2 (6). - P. 53-58.

14. Порівняльна оцінка гастротоксичності похідних 4-оксо(аміно-) хіназоліну (сполук ПК-66 та ПК-199), диклофенаку та кеторолаку при їх тривалому введенні в організм / А. І. Юрченко, Г. І. Степанюк, О. І. Альчук [та ін.] // Укр. біофрармац. журн. - 2014. - № 6 (35). C. 60-63.

15. Experimental study of pain-relieving mechanisms of 4-[4-oxo-(4h)-quinazolin-3-yl]-benzoic acid (pk-66 compound) / H. Kramar, H. Stepaniuk, N. Voloshchuk [et al.] // Georgian Medical News. -2018. - No. 10 (283). P. 148-154.

16. Павленко А. Ю. Болевой синдром: патофизиологические механизмы развития и методы воздействия на этапах оказания медицинской помощи / А. Ю. Павленко, А. А. Хижняк // Медицина неотложных состояний. - 2006. - № 1 (2). - С. 16-19.

17. Чурюканов В. В. Нейрохимический анализ и фрармакологическая регуляция кортикофругальных механизмов контроля ноцицептивных сигналов в аффрерентных путях / В. В. Чурюканов // Эксперим. и клинич. фрармакология. - 2003. - № 2. - С. 24-31.

18. Побережный В. И. К вопросам феномена "боль". Формулирование дефиниции "боль" на основе 
системного подхода / В. И. Побережный, А. В. Марчук // Pain Medicine. - 2016. - № 1. - C. 6-21.

19. Кукушкин М. Л. Общая патология боли / М. Л. Кукушкин, Н. К. Хитров. -М. : Медицина, 2004. $144 \mathrm{c}$.

20. Cross-modal plasticity in the human thalamus: evidence from intraoperative macrostimulations / A. K. Jetzer, A. Morel, M. Magnin, D. Jeanmonod // Neuroscience. - 2009. - No. 164. - P. 1867-1875.

21. Фармакологическая регуляция воспаления / Ф. П. Тринус, Б. М. Клебанов, И. М. Ганджа, Р. Д. Сейфрулла. - К. : Здоров'я, 1987. - 144 с.

22. Яковлева Л. В. Експериментальне вивчення нових противиразкових препаратів / Л.В.Яковлева, Г.В.Оболенцева, Л.П.Брюзгінова // Доклінічні дослідження лікарських засобів : метод. рек. / за ред О. В. Стефранова. - К. : Авіцена, 2001. - С. 321-333.

\section{REFERENCES}

1. Bykov, Yu.N., Levina, G.Yu., \& Alekseev, S.B. (2015). Diagnostika i lechenie neyropaticheskoy boli pri zabolevaniyakh perifericheskoy nervnoy sistemy [Diagnosis and treatment of neuropathic pain in diseases of the peripheral nervous system]. Sibirskiy meditsinskiy zhurnal - Siberian Medical Journal, 3, 28-30 [in Russian]

2. Zozulia, I.S., Maksymenko, M.V., \& Zozulia, A.I. (2016). Bil: pidkhody do diahnostyky ta likuvannia v nevrolohii ta khirurhii [Pain: approaches to diagnosis and treatment in neurology and surgery]. Ukr. medychnyi chasopys - Ukrainian Medical Journal, 2 (112), $37-39$ [in Ukrainian].

3. Korzh, A.N. (2017). Ostryy bolevoy sindrom v praktike semeynogo vracha [Acute pain in the practice of a family doctor]. Retrieved from: http://www.mif-ua com/archive/article/44421\#prettyPhoto.

4. Clarke, T.C., Nahin, R.L., Barnes, P.M., \& Stussman, B.J. (2016). Use of complementary health approaches for musculoskeletal pain disorders among adults: United States, 2012. Natl. Health Stat. Report., 98, 1-12.

5. Mamchur, V.Y., \& Khomiak, O.V. (2011). Depresiia ta bil: deiaki pytannia komorbidnosti ta likuvannia (ohliad) [Depression and pain: Some issues of comorbidity and treatment (review)]. Morfolohiia - Morphology, 3, 24-34 [in Ukrainian].

6. Torrance, N., Elliott, A., Lee, A., \& Smith, B. (2010). Severe chronic pain is associated with increased 10 year mortality. Acohort record link-age study. European Journal of Pain, 14, 380-386.

7. Morgan, B., \& Wooden, S. (2018). Diagnosis and treatment of common pain syndromes and disorders. Nurs. Clin. North. Am., 53, 3, 349-360. DOI: 10.1016/j. cnur.2018.04.004

8. Khodakivskyi, O.A. (2009). Neiroprotektorna diia pokhidnykh 4-okso(amino-) khinazolinu pry eksperymentalnii ishemii holovnoho mozku [Neuroprotective effect of derivatives of 4-oxo (amino) quinazoline in experimental cerebral ischemia]. Extended abstract of
23. Ланг Т. А. Как описывать статистику в медицине. Руководство для авторов, редакторов и рецензентов / Т. А. Ланг, М. Сесик ; пер. с англ. под ред. В. П. Леонова. - М. : Практическая медицина, 2011. $480 \mathrm{c}$.

24. Порівняльна оцінка впливу 4-[4-оксо-(4Н)-хіназолін-3-іл] бензойної кислоти (сполука ПК-66) та диклофенаку на перебіг ад'ювантного артриту у щурів / А. І. Юрченко, Г. І. Степанюк, С. І. Коваленко [та ін.] // Фармакологія та лікар. токсикологія. -2015. № 4-5 (45). - C. 103-107.

25. Ricciotti E. Prostaglandins and inflammation / E. Ricciotti, G. A. FitzGerald // Arterioscler. Thromb. Vasc. Biol. - 2011. - 31 (5). - P. 986-1000.

26. Brune K. New insights into the use of currently available non-steroidal anti-inflammatory drugs / K. Brune, P. Patrignani // J. Pain Res. - 2015. - No. 8. P. 105-118.

Candidate's thesis. Odesa: Odesa State Medical University [in Ukrainian].

9. Alchuk, O.I. (2011). Aktoprotektorni vlastyvosti novykh pokhidnykh 4-okso(amino-)khinazolinu (eksperymentalne doslidzhennia) [Actoprotective properties of new 4-oxo (amino-) quinazoline derivatives (experimental study)]. Extended abstract of Candidate's thesis. Kyiv: Institute of Pharmacology and Toxicology, of AMS of Ukraine [in Ukrainian].

10. Yurchenko, A.I. (2013). Skryninh analhetychnoi dii pokhidnykh 4-okso(amino-) khinazolinu [Screening of analgesic action of 4-oxo (amino) quinazoline derivatives]. Farmakol. ta likarska toksykolohiia - Pharmacological and Medicinal Toxicology, 2 (33), 89-91 [in Ukrainian].

11. Pavlov, S.V. (2007). Tserebroprotektyvna aktyvnist pokhidnykh (4-okso-4-N-khinazolin-3-il)-alkil (aryl) karbonovykh kyslot $v$ umovakh imobilizatsiinoho stresu [Cerebroprotective activity of (4-oxo-4-H-quinazolin-3-yl)alkyl (aryl) carboxylic acid derivatives under conditions of immobilization stress]. Extended abstract of Candidate's thesis. Kyiv: Institute of Pharmacology and Toxicology of AMS of Ukraine [in Ukrainian].

12. Kramar, H.I. (2017). Experimental study of analgesic effect of new 3-(2-R1-6-R2-4-oxyquinoline$3(4 \mathrm{H})$-yl)alkyl (alkaryl, aryl) carboxylic acid derivative (PC-66 compound). Curierul Medical, 1, 32-34.

13. Kramar, H.I. (2017). Experimental study of state of gastric mucosa in rats under introduction of new derivate of 4-[4-oxo-4h-quinazoline-3-yl] benzoic acid (pc-66). ScienceRise: Pharmaceutical Science, 2 (6), 53-58.

14. Yurchenko, A.I., Stepaniuk, H.I., Alchuk, O.I., Kovalenko, S.I., \& Shabelnyk, K.P. (2014). Porivnialna otsinka hastrotoksychnosti pokhidnykh 4-okso(amino-) khinazolinu (spoluk PK-66 ta PK-199), dyklofenaku ta ketorolaku pry yikh tryvalomu vvedenni $v$ orhanizm [Comparative evaluation of the gastro-toxicity of 4-oxo (amino-) quinazoline derivatives (PK-66 and PK-199), diclofenac and ketorolac derivatives with prolonged 
administration]. Ukrainskyi biofarmatsevtychnyi zhurnal Ukrainian Biopharmaceutical Journal, 6 (35), 60-63 [in Ukrainian].

15. Kramar, H., Stepaniuk, H.I., Voloshchuk, N.I., Taran, I.V., Alchuk, O.I., Kovalenko, S.I., \& Schabelnyk, K.P. (2018). Experimental study of pain-relieving mechanisms of 4-[4-oxo-(4h)-quinazolin-3-yl]-benzoic acid (PK-66 compound). Georgian Medical News, 10 (283), 148-154.

16. Pavlenko, A.Yu., \& Hizhniak, A.A. (2006). Bolevoy sindrom: patofiziologicheskie mekhanizmy razvitiya $\mathrm{i}$ metody vozdeystviya na etapakh okazaniya meditsinskoy pomoshchi [Pain syndrome: pathophysiological mechanisms of development and methods of exposure in the stages of care]. Meditsina neotlozhnykh sostoyaniy Emergency Medicine, 1 (2), 16-19 [in Ukrainian].

17. Churyukanov, V.V. (2003). Neyrohimicheskiy analiz i farmakologicheskaya regulyatsiya kortikofugalnykh mekhanizmov kontrolya notsitseptivnyh signalov v afferentnykh putyakh [Neurochemical analysis and pharmacological regulation of corticofugal mechanisms for controlling nociceptive signals in afferent pathways]. Eksperim. $i$ klinich. farmakologiya - Experimental and Clinical Pharmacology, 2, 24-31 [in Russian].

18. Poberezhnyy, V.Y., \& Marchuk, A.V. (2016). K voprosam fenomena "bol". Formulirovanie definitsii "bol" na osnove sistemnogo podkhoda [To the issues of the "pain" phenomenon. Formulation of the definition of "pain" based on a systematic approach]. Pain Medicine, 1, 6-21 [in Russian].

19. Kukushkin, M.L., \& Hitrov, N.K. (2004). Obshchaya patologiya boli [General pathology of pain]. Moscow: Meditsina [in Russian]
20. Jetzer, A.K. (2009). Cross-modal plasticity in the human thalamus: evidence from intraoperative macrostimulations. Neuroscience, 164, 1867-1875.

21. Trinus, F.P., Gandzha, I.M., Klebanov, B.M., \& Seyfulla, R.D. (1987). Farmakologicheskaya regulyatsiya vospaleniya [Pharmacological regulation of inflammation]. Kyiv: Zdorovia [in Russian].

22. Yakovleva, L.V., Obolentseva, H.V., \& Briuzhinova, L.P. (2011). Eksperymentalne vyvchennia novykh protyvyrazkovykh preparativ. Doklinichni doslidzhennia likarskykh zasobiv: method. recomen. [Experimental study of new antiulcer drugs. Preclinical drug research: guidelines]. Stefanov, O.V. (Ed.). Kyiv: Avitsena [in Ukrainian].

23. Lang, T.A., \& Sesik, M. (2011). Kak opisyvat statistiku $v$ meditsine [How to describe statistics in medicine]. Annotated Guide for Authors, Editors, and Reviewers: trans. from English. Moscow: Prakticheskaya meditsina [in Russian].

24. Yurchenko, A.I., Stepaniuk, H.I., Alchuk, O.I. Kovalenko, S.I., \& Shabelnyk, K.P. (2015). Porivnialna otsinka vplyvu 4-[4-okso-(4H)-khinazolin-3-il] benzoinoi kysloty (spoluka PK-66) ta dyklofenaku na perebih adiuvantnoho artrytu u shchuriv [Comparative evaluation of the effect of 4- [4-oxo- (4H) -quinazolin-3-yl] benzoic acid (PC-66 compound) and diclofenac on the course of adjuvant arthritis in rats]. Farmakol. ta likarska toksykolohiia - Pharmacological and Medicinal Toxicology, 4-5 (45), 103-107 [in Ukrainian].

25. Ricciotti, E., \& FitzGerald, G.A. (2011). Prostaglandins and inflammation. Arterioscler Thromb. Vasc. Biol., 31(5), 986-1000.

26. Brune, K., \& Patrignani, P. (2015). New insights into the use of currently available non-steroidal antiinflammatory drugs. J. Pain Res., 8, 105-18.

А. И. Крамар, Г. И. Степанюк, Н. И. Волощук, А. И. Альчук ВИННИЦКИЙ НАЦИОНАЛЬНЫЙ МЕДИЦИНСКИЙ УНИВЕРСИТЕТ ИМЕНИ Н. И. ПИРОГОВА

\section{ЭКСПЕРИМЕНТАЛЬНОЕ ИССЛЕДОВАНИЕ МЕДИАТОРНЫХ МЕХАНИЗМОВ АНТИНОЦИЦЕПТИВНОГО ДЕЙСТВИЯ 4-[4-ОКСО-(4Н)-ХИНАЗОЛИН-3-ИЛ] БЕНЗОЙНОЙ КИСЛОТЫ (СОЕДИНЕНИЯ ПК-66)}

\section{Резюме}

Вступление. В предыдущих исследованиях установлено, что среди производных 4-оксо (амино-) хиназолина веществом-лидером с выраженным обезболивающим действием на разных моделях болевой перцепции является 4-[4-оксо-(4Н)-хиназолин-3-ил] бензойной кислоты (соединение ПК-66).

Цель исследования - основательно изучить главные механизмы аналгетического действия нового оригинального производного хиназолина - соединения ПК-66.

Методы исследования. Антиноцицептивное действие соединения ПК-66 (1 мг/ка внутрибрюшно) изучали у крыс на модели гипералгезии, вызванной субплантарным введением в левую заднюю конечность животного 0,1 мл 1 \% раствора каррагенина, 2 \% суспензии зимозана и 0,01 \% раствора брадикинина. Степень ноцицепции определяли с помощью долориметра путем оценивания порога болевой чувствительности. В качестве референс-препаратов использовали диклофренак натрия (4 мг/кг) и корвитин (5 мг/к2). Аналгетическую активность исследуемых соединений оценивали по их способности увеличивать порог болевой чувствительности в исследовательских группах по сравнению с группой контроля и выражали в процентах. Антиэкссудативную активность соединения и рефреренс-препаратов определяли путем измерения объема отека лапки с помощью плетизмометра по степени уменьшения отека у подопытных животных по сравнению с крысами группы контроля и выражали в процентах. 
Результаты и обсуждение. Соединение ПК-66 способно устранять гипералгезию, которую вызвали разные альгогены. Наиболее выражено ее обезболивающее действие проявлялось на фроне введения брадикинина (53,4 \%), менее выраженную антиноцицепцию наблюдали при каррагениновом отеке (38,5%), наименее выраженным это действие было на модели зимозановой гипералгезии (26,9%). Исследование антиэкссудативного действия продемонстрировало, что антифрлогогенное действие соединения ПК-66 в большей степени проявлялось на модели каррагенинового отека (16,1%), чем зимозанового (12,8 \%). Однако этот эфрфект не достигал статистически достоверных значений ни при каррагениновом, ни при зимозановом отеке и в обоих случаях значительно уступал препаратам сравнения - диклофенаку натрия (58,3\%) и корвитину (52,3\%).

Вывод. Антимедиаторное действие соединения ПК-66 в большей степени обусловлено антагонизмом к брадикинину, в меньшей - к простагландинам и лейкотриенам.

КЛЮЧЕВЫЕ СЛОВА: 4-[4-оксо-(4Н)-хиназолин-3-ил] бензойной кислоты; ноцицепция; медиаторные механизмы; брадикинин.

H. I. Kramar, H. I. Stepaniuk, N. I. Voloshchuk, O. I. Alchuk NATIONAL PIROGOV MEMORIAL MEDICAL UNIVERSITY, VINNYTSYA

\section{EXPERIMENTAL STUDY OF THE MEDIATOR MECHANISMS OF THE ANTINOCYCEPTIVE ACTION OF 4-[4-OXO-(4H)-QUINAZOLIN-3-YL]-BENZOIC ACID}

\section{Summary}

Introduction. Previous studies have found that among derivatives of 4-oxo (amino) quinazoline, a leading substance, with pronounced analgesic action on different models of pain perception is 4- [4-oxo-4h-quinazolin-3-yl] benzoic acid (PK-66 compound).

The aim of the study - in-depth study of the main mechanisms involved in the implementation of analgesic action of a new original quinazoline derivative - PK-66 compounds.

Research Methods. Evaluation of the antinociceptive action of PK-66 (1 mg/kg i/h) was studied in rats, modeled on hyperalgesia, caused by the introduction of $0.1 \mathrm{ml}$ of $1 \%$ solution of carrageenin, $2 \%$ suspension of zymosan and $0.01 \%$ solution of bradykinin, which was injected subplantarly in left hind limb of an animal. The degree of nociception was determined using a dollarimeter by estimating the pain threshold. Diclofenac sodium (4 mg/kg) and corvitin (5 mg/kg) were used as reference drugs. The analgesic activity of the test compounds was evaluated by their ability to increase the pain threshold in the study groups compared to the control group and was expressed as a percentage. The anti-exudative activity of the compound and the reference preparations was determined by measuring the volume of paw edema using a plethysmometer. The degree of reduction of swelling in the experimental animals compared to the control group animals and was expressed as a percentage.

Results and Discussion. Compound PK-66 has the ability to eliminate hyperalgesia caused by various algogens. Its most pronounced analgesic effect was manifested against the introduction of bradykinin (53.4 \%), less pronounced antinociception was found in carrageenan edema (38.5\%), and the least pronounced effect was on the model of zymosan hyperalgesia (26.9\%). The anti-exudative effect study showed that the degree of antiflogogenic action of PC-66 was more pronounced in the carrageenan swelling model (16.1\%) than zymosan (12.8\%). However, this effect did not reach statistically significant values for either carrageenan or zymosan edema, and in both cases was significantly inferior to the comparison drugs - diclofenac sodium compound (58.3\%) and corvitin (52.3\%).

Conclusion. The anti-mediating effect of PK-66 is more due to antagonism to bradykinin, to a lesser extent to prostaglandins and leukotrienes.

KEY WORDS: 4- [4-oxo (4H) -quinazolin-3-yl] benzoic acid; nociception; mediator mechanisms; bradykinin.

Адреса для листування: Г. І. Крамар, Вінницький національний медичний університет імені М. І. Пирогова, вул. Пирогова, 56, Вінниця, 21000, Україна, е-mail: annachivanna@gmail.com. 